https://helda.helsinki.fi

\title{
Encountering religious diversity : multilevel governance of Islamic education in Finland and Ireland
}

\section{Sakaranaho, Tuula Helena}

2018

Sakaranaho, T H 2018 , ' Encountering religious diversity : multilevel governance of Islamic education in Finland and Ireland ', Journal of Religious Education, vol. 66 , no. 2 , pp. 111-124 . https://doi.org/10.1007/s40839-018-0065-9

http://hdl.handle.net/10138/305123

https://doi.org/10.1007/s40839-018-0065-9

acceptedVersion

Downloaded from Helda, University of Helsinki institutional repository.

This is an electronic reprint of the original article.

This reprint may differ from the original in pagination and typographic detail.

Please cite the original version. 


\title{
Encountering Religious Diversity. The Governance of Islamic Education in Finland and Ireland.
}

Tuula Sakaranaho

Study of Religions, University of Helsinki, Helsinki, Finland

\author{
Tuula Sakaranaho \\ Professor \\ Faculty of Theology \\ Study of Religions \\ P.O. Box 59 (Unioninkatu $38 \mathrm{E}$ ) \\ FIN-00014 University of Helsinki \\ Finland
}

Phone: + $358294124334,+358504160748$

Email: tuula.sakaranaho@ helsinki.fi

Orcid: 0000-0001-7298-879X

\section{Encountering Religious Diversity. The Governance of Islamic Education in Finland and Ireland.}

\begin{abstract}
Recent decades have witnessed a change in European governments' policies from benign neglect to active management of religious diversity, where Islam is often seen as the most challenging for the European social order. However, the ways that this "management" is justified and undertaken varies from country to country and depends on the issues at hand. This paper will take up the issue of Islamic education in Finland and Ireland where it is incorporated into the public school system and where the state has taken an active role in order to control Islam in the field of education. The main argument of this article is that the "management" of Islamic education in both of the above-mentioned countries is ridden with contradictions arising from the difficulty to balance between an emphasis on particular national traditions, on the one hand, and public policies concerning religious diversity, on the other hand. Theoretically, the article will employ the perspective of multilevel governance which helps to widen the perspective from the state as a primary explanatory factor (formal processes of governance) to different agents of the civil society (informal processes of governance), in encountering religious diversity.
\end{abstract}

Keywords: multilevel governance, religious diversity, Islamic education, Finland, Republic of Ireland 


\section{Introduction}

Recent decades have witnessed a change in European governments' policies from benign neglect to active management of religious diversity, where Islam is often seen as the most challenging for the European social order (Laurence 2012) and Muslims as a "policy problem" to be "managed" (Koenig 2007). However, the ways that this "management" is justified and undertaken varies from country to country and depends on the issues at hand. In general, it seems that European states increasingly demand loyalty of their citizens to the nation state and its core value and education is one of the most important means to uphold these values (Himanen 2012.) In order to discuss these general arguments, this paper will take up the topic of Islamic education, and with respect to European countries, will focus on Finland and the Republic of Ireland. In both countries, Islamic education is incorporated into the state-supported public school system, so that in Finland Islam is taught as one of the school subjects and in Ireland it is taught in Islamic schools. Thus, in both countries, albeit within different educational systems, the state has taken an active role in order to monitor and control Islam in the field of education. (Sakaranaho and Martikainen 2015; see also Rissanen and Sai 2017.)

As a result of globalization, there are people in EU countries such as Finland and Ireland, who represent religious traditions that have no historical lineage in the country and do not necessarily fit into the institutional structure that has been established in interaction between the state and dominant Christian church. However, when looking at the cases of Finland and Ireland, it is obvious that Christian institutional structures constitute, explicitly or implicitly, a normative model for the organization of religions, and hence religious communities new to the country need to fit in one way or another into the historically evolved church and state relations. (Sakaranaho 2006.) The institutional necessities and benefits that can be drawn from these historically evolved church and state relations are also obvious in the way that Islamic education is organized and managed in Finland and Ireland. However, what this article will argue is that encountering religious diversity within readymade, hierarchical structures that constitute a norm easily leads to discrepancies between the official rhetoric of equality, on the one hand, and that of legal and social practice, on the other hand. In the following, I will first outline my theoretical starting point and then delve into the cases of Finland and Ireland. 
Theoretically, this article will employ the perspective of governance, which to date has not gained much attention in studies on the public policies concerning religious and cultural diversity in Finland (Martikainen 2007; Martikainen 2013) or Ireland (Sakaranaho 2015; Sakaranaho forthcoming). The aim of this article is not to make comparison between these two countries but rather use them as an example in order to highlight issues in relation to the governance of religious diversity (cf. Bråten 2013).

In contemporary studies on religion in the public sphere, there has been a move from a narrow understanding of "government" to a broader view of "governance" in order to understand the changed power relations in western state structures, and this is also increasingly noted in the study of Islam in Europe (Bader 2007; Maussen 2007). The perspective of government entails an understanding which emphasizes the importance of the state as a primary explanatory factor, whereas the perspective of governance is linked to the process of intensified globalization and the emergence of new forms of public management at "the age of neoliberalism", whereby the state is increasingly relying on different agents of the civil society in its encounter with social, cultural and religious diversity (Martikainen 2013; Gauthier and Martikainen 2013; see also Burchardt 2017).

In brief, the perspective of government concerns the action-coordination between the state and social actors by a public hierarchy consisting of laws, rules and regulations (Bader 2007). As an example, one can mention national constitutions and laws on religious freedom, addressing religious rights most directly. Naturally, the right to religious education can be seen as one of the religious rights but also as a right pertaining to legal principles of equality. The official parameters of education in turn are covered in different educational acts and overall regulations such as national syllabus for primary and secondary education in state-supported schools.

In this article, a perspective of government will be understood as a formal process of governance. In general, questions about religion and law have often been perceived in the framework of particular relations between church and state whereby differences and similarities between different national cases have been elicited. Even if somewhat "outdated" as a model of explanation for the ways that states interact with religions, it still has a role to play as part of larger picture consisting of supranational and national processes. (Martikainen 
2015; Sakaranaho and Martikainen 2015.) Consequently, it is necessary to look at religious education in relation to church-state relations and the same concerns Islamic education.

In addition to formal processes, the perspective of governance also takes into account matters outside the direct influence of the state and hence it pays attention to informal processes pertaining to practice. With respect to informal processes of governance, this paper will utilize the perspective of multilevel governance which creates opportunities for a type of analysis that goes beyond the study of formal legal arrangements, and also looks at processes of application, implementation and interpretation. (Sakaranaho and Martikainen 2015; Sakaranaho forthcoming.) With respect to religious education, this approach widens the perspective from laws concerning education and national regulation of religious education by means of overall curricula, to the questions as to how religious education is put into practice. Hence, it can cover local bodies, schools, teachers and pupils as well parents in the interaction involved around religious education in general and, with respect to this article, around Islamic education in particular. Paying attention to the governance of religious education on different levels of hierarchy is important when studying the relations between "normative models of appropriate institutions and policies and 'what is going on the ground." (Bader 2007).

In the following, I will first focus on the formal processes of governance where the state is in focus and second will bring up some issues involved in the informal governance of Islamic education, in the respective countries.

\section{Finland and Ireland: Religious Diversity and a Model of Extended Privileges}

Both Finland and Ireland are small countries at the fringes of Europe, where the effects of immigration to Europe after the Second World War were felt rather late in comparison to some other European countries, such as France, Britain and Germany. Till the 1990s, both Finland and Ireland were countries of emigration rather than of immigration. In recent decades the situation has changed and both countries are now receiving immigrants in numbers that they would not have anticipated prior the 1990s. This change notwithstanding, compared to other European countries, the numbers involved are still rather small. For instance, of the estimated 19 million Muslims in the EU, there are around 70000 Muslims both in Finland and in the Republic of Ireland. This said, however, it must be noted that the numbers do not tell the whole story. Both Finland and Ireland have been on a steep policy learning curve for the past decades and thereby have undergone major changes in education 
and social welfare systems in order to accommodate a growing religious and cultural diversity in their countries. (Sakaranaho 2006.)

Both countries have a majority church, i.e. the Evangelical Lutheran Church in Finland and the Roman Catholic Church in Ireland, that has exerted significant influence on the state and, in spite of rapid social change, still do so at least to some extent. Hence, in both countries, there is a particular legacy of relations between state and church that have a bearing on state policies concerning education and other field of society. As a short hand, I will call these a Lutheran legacy in case of Finland and a Catholic legacy in case of Ireland, to be discussed in more detail below. Even though under different legal arrangements of church-state relations, both Finland and Ireland have opted for a policy with respect to religious diversity where they aim at securing the status quo of a dominant (national) church while also extending some of the legal privileges enjoyed by the mainstream church to religious minorities. I call this a model of extended privileges. (Sakaranaho 2006; see also Sakaranaho and Martikainen 2015.) It also informs the way that Islamic education is formally organized and managed in the respective countries. Consequently, it is necessary to pay attention to the ways that the management of Islamic education in Finland and Ireland reflects the hierarchical top down model of governance traditionally attached to the historical relations between church and state.

\section{Right to Religious Education in Finland}

According to the Constitution of Finland (Suomen perustuslaki) "Everyone is equal before the law", and no one should be treated differently from other persons on the ground religion and conviction, among other things. With respect to religious freedom, section eleven (11 $)$ of the Constitution states the right to religious belief, practice and belonging, whereby the belonging is explicated as a membership of a religious community. (Constitution of Finland 731 / 1999, 2011.) Thus, regarding the manifestation of one's religion in community with others, the law seems to reiterate the understanding of religious belonging as a membership, which undoubtedly is characteristic of the national churches in Finland and other Nordic countries. However, membership as a mode of religious belonging is not necessarily customary in all religions of which Muslims constitute one clear example; only less than $15 \%$ of Muslims have a membership in one of the registered Islamic communities in Finland. (Pauha \& Martikainen 2014.) In this respect, the law rearticulates an established Lutheran 
model of religious belonging and fails to reflect the multi-faith scene of Finnish society (see Sakaranaho 2006, 129ff.). The same can be said about religious education.

The current Freedom of Religion Act (Uskonnonvapauslaki 2003/453) grants the right of children belonging to different religious communities to receive "education in accordance with their own religion" (oman uskonnon opetus) as a part of the school curriculum. Moreover, the right for religious education is passed separately in the Comprehensive Education Act (Peruskoululaki 454/2003) and in the Upper-secondary Education Act (Lukiolaki 455/2003) which state that the comprehensive schools, i.e. the primary schools (alakoulu) and the secondary schools (yläkoulu), as well as the upper-secondary schools (lukio), are obliged to provide their pupils and students respectively with religious education or education of Ethics, as a part of the school curriculum.

Even though religious education in Finland is divided according to religious traditions, and hence is "separative" (Alberts 2007) or "pluralist monoreligious" (Ubani 2013) or "singlefaith (Rissanen 2014), it should not however be confessional so that it would serve the purposes of a religious community and nor should it include religious practice (Sakaranaho 2013). The move away from confessional to non-confessional religious education in Finland has taken place gradually over the decades when the linkage between the Lutheran Church and school education have be severed and religious education has been put on the same footing with other school subjects where the aims of the comprehensive school dictate their contents. (Seine 2000.) Thus, the current model of religious education is a result of a particular kind of historical process that has in principle concerned Lutheran RE. It is currently a model that also other religious communities need to comply with irrespective of their views and needs. (Sakaranaho \& Salmenkivi 2009.)

In any case, the organisers of comprehensive and upper-secondary education, i.e. municipalities (see Ubani 2013), are first obliged to arrange religious education of the majority. Since around $70 \%$ of the Finnish people are members of the Lutheran Church, it is the Lutheran religious education which in practice is predominant in Finnish schools. Due to small numbers of other faith-communities, it is hard to see any non-Lutheran religious community reaching a majority in Finland in the foreseeable future. One can therefore conclude that, in practice, the provision reifies the position of the Lutheran religious education as a fundamental part of the Finnish education in comprehensive and uppersecondary schools. 
The reification of the Lutheran education is furthermore obvious in that pupils belonging to the Lutheran Church do not only have a right to participate in the education of her or his religion but are obliged to do so. In addition, pupils belonging to some other religious community, or no religious community at all, are allowed, if their parents so wish, to participate in Lutheran RE. In this respect, the law, by curtailing the freedom of choice for the Lutheran pupils, would seem to discriminate against the members of the majority religion (see Scheinin 2001).

The aforementioned provision on religious education also states that the municipalities are obliged to organise religious education for three pupils or students belonging to the Lutheran Church or to the Finnish Orthodox Church, not attending the religious instruction of the majority. In contrast to other minority religions, municipalities are obliged to arrange Orthodox RE as soon as they have three Orthodox pupils or students, and no request from the parents or students is needed. For members of religious communities other than those of the Lutheran or Orthodox faiths, religious education should be organised if there are three pupils or students in the area of a municipality belonging to a particular registered religious community, and if the parents of these pupils, in the case of comprehensive schools, or students themselves in the case of upper-secondary school, so request. Thus, in contrast to the compulsion of the Lutheran RE, the education of the minority religions, other than that of the Orthodox, is distinctively voluntary and is, at least in principle, left to the activity of the parents or students themselves.

In addition to religious education, municipalities are also obliged to organise the education of Ethics for those pupils who are not members of any religious community, and who do not participate in Lutheran education. The minimum requirement of pupils is three, but the request of parents is required only in cases where a pupil is a member of a religious community but the municipality does not organise education in her or his religion. Therefore, the education of Ethics is on the same standing with the Orthodox RE.

Reading the above-mentioned provisions, it is obvious that they base the right for religious education first and foremost on membership of a religious community (cf. Seppo 2003: 179). In so doing, they clearly reflect the general conception of religious affiliation in Finland, which does not primarily concern believing or behaving in a certain way, but rather concerns membership of the Finnish Lutheran Church - more or less taken for granted in Finland. However, the emphasis on membership can prove to be problematic for adherents of religions 
which are not organised in line with registered membership. This was also voiced by different Christian and Muslim communities in their criticism of the current Freedom of Religion Act (2003). In their view, the Act reiterates dominant language of religious belonging and constructs the Lutheran understanding as a norm that other religious communities need to comply with. (Sakaranaho 2006.)

In any event, fostering plurality of religious education is seen, from the state point of view, as a benevolent gesture of recognition towards different religious communities. As a result of growing religious pluralism in Finland, the number of pupils availing themselves of the right for religious education at school is increasing rapidly. (Sakaranaho and Salmenkivi 2009; Ubabi 2013.) This is particularly so in the case of Islam where the number of Muslim pupils in the metropolitan area of Helsinki is constantly expanding. Unlike many other European countries, in Finland no ethnic group of Muslims dominates the community living in the country. Thus, apart from a rather small number, Muslims in Finland constitute a very heterogeneous population with various ethnic, linguistic and religious differences.(Pauha \& Martikainen 2014.)

The diversity of Muslims notwithstanding, only one type of Islam, understood as some sort of general Islam suited to both the Sunni and Shia, is taught in Finnish schools. However, in actual teaching it is the Sunni interpretation of Islam that tends to dominate (Rissanen and Sai 2017). Thus, the law acknowledges the right of Muslims to have Islamic RE as part of school curriculum but does not recognize the religious diversity among Muslims following different traditions. In itself, this is as an example of the limits of the model of extended privileges mentioned above and a sort of discrimination it can produce.

\section{Catholic Legacy and Denominational Education in Ireland}

The Constitution of Ireland (Bunreacht na hÉireann) is very different from the Finnish constitution in that it starts with a preamble that honours the Most Holy Trinity and acknowledges the obligation of the Irish people to Divine Lord, Jesus Christ. At the same time, Article 3 of the Constitution states that the aim of the Irish nation is "to unite all the people who share the territory of the island of Ireland, in all the diversity of their identities and traditions", and that this unity can be brought about by "the peaceful means with the consent of the majority of the people". In similar fashion to the Finnish constitution, Article 
40 of the Irish constitution states that all citizens "shall be held as equal before the law". The Article 44 on freedom of religion, again, reiterates the religious language of the Preamble by starting with a reference to Almighty God and to the obligation of the state to respect and honour religion in Ireland. It then goes on saying that "The State guarantees not to endow any religion".

The aim "not to endow any religion" is articulated in the provision of Article 44 stating that, with respect to providing State aid for schools, legislation "shall not discriminate between schools under the management of different religious denominations, nor be such as to affect prejudicially the right of any child to attend a school receiving public money without attending religious instruction at that school". Moreover, it states that "Every religious denomination shall have the right to manage its own affairs, own, acquire and administer property, movable and immovable, and maintain institutions for religious or charitable purposes." This is iterated also in The Rules for National Schools (1965: 9) stating that "these Rules do not discriminate between schools under the management of different religious denominations".

Even though the denominational school system in Ireland evokes heated debate (see Murray 2008; Hogan 2011), at least for the time being, it has firm roots in the Constitution of Ireland and hence in practice. For historical reasons, there is a particular legacy in Ireland of resistance to the idea of state schools (Whyte 1980). Hence, the role of the state is to provide premises and sufficient finance for schools, while the schools are managed and run by trustees. Moreover, a similar arrangement also concerns teachers who are paid by the state but have a contract with school trustees. With respect to these trustees, the vast majority of schools are owned or managed by Catholic parishes or religious orders. In addition, there are some Protestant schools and a few schools owned by other religious communities, such as Jews and Muslims, as well as a growing number of multi-denominational schools. (Sakaranaho 2015.)

The denominational system of education in Ireland has ensured that different religious communities, in addition to the Catholic majority, have been able to socialise children in their respective religious traditions. Therefore, it is not surprizing that the start of the first Muslim primary school in Ireland went rather smoothly, and was even recognized by the state so that it was officially opened in April 1993 by the President of Ireland, Mrs Mary Robinson. The 
second Muslim primary school started, without much publicity, in September 2001 and thus today there are two Muslim primary school in Dublin. Both of the schools are run under the patronage of the Islamic Foundation of Ireland (IFI) and have schools boards with representatives of Muslims parents. The principals and teachers of both schools, excluding teachers of Islam and Arabic, are non-Muslim. (Islamic Foundation of Ireland; Sakaranaho 2015; Sai 2017.)

However, a recent report on education and anti-racism in Ireland pointed out that the Irish system of education is failing to sufficiently address the needs of families who are not Catholics. The present situation, where most of the schools are under the ownerships and management of the Catholic Church, and where, therefore, only one per cent of the schools are multidenominational, leaves very little choice for parents with respect to their children's education. (O'Loinsigh 2001.) This is also true for Islamic schools whose role as offering Islamic education to Muslim children is very limited when taking into consideration that only two primary schools exist in the country and both of them are in Dublin. Consequently, most of the Muslim children are educated in Catholic schools and some in Protestant schools. Contrary to Finland, in Ireland schools are obliged to give religious education only in accordance of their own religious ethos and therefore Muslim children are forced to attend Catholic RE or are withdrawn from it by their parents, using their constitutional right to do so. (Cullen 2005; Sakaranaho 2015.)

Another issue that can be problematic from the point of view of Muslim pupils is that the schools ethos is fostered by integrated curriculum where religion is taught not simply as a separate subject but as a part of the entire school curriculum. In other words, the particular religious ethos is supposed to permeate the entire school community and inform all subjects taught in school as well as its social and cultural activities. (Cullen 2005; Sakaranaho 2006.) Consequently, a more general question remains as to how the Irish majority schools will, in accordance with the Education Act (1998), accommodate the religious and cultural needs of their pupils, and deal with the consequent "implications for these schools in terms of change in managements structures, in terms of change in ethos and in terms of the resourcing of these schools". (O’Loinsigh 2001; Sakaranaho 2006.) A further problem that Muslims face in Ireland is the admission to secondary schools. Especially, Muslim girls have experienced problems in being admitted to (Catholic) secondary schools on the grounds that wearing an Islamic head scarf (hijab) violates the Catholic ethos of the school. (McGarry 2000.) 
In sum, one may note that the governance of religious education in Ireland in accordance with the model of extended privileges, whereby the status quo of the Catholic schools remains intact but where the denominational school system ensures for religious minorities the right to run schools in accordance with their religious ethos, has serious limitations, and, what is more important, in a sense makes redundant addressing topical issues concerning religious diversity in Irish schools in general.

\section{Islamic education in practice}

\section{Teaching Islamic RE in Finland}

Since Islam is such a new subject in Finnish schools it has not, naturally enough, been established in the same manner as the Lutheran RE, where teacher training is organised by three different universities and text-books and teacher guides abound. Due to being such a recent subject, Islamic RE is also more disadvantaged in comparison with the education of Orthodox and Catholic RE. Both of the last-named religions have clear institutional ties with their respective churches. With regard to teacher training, Orthodox teachers are trained in the University of Joensuu, and Catholic teachers at the University of Helsinki. With respect to the latter, the Catechetic Centre of the Catholic Church in Helsinki gives support to its own teachers and also helps to produce text-books for Catholic RE. Islamic education does not enjoy such direct institutional benefits. (Sakaranaho 2006.)

In order to provide teachers of Islam with formal qualifications, the University of Helsinki started in 2007 teacher training in Islamic RE. However, it has managed to attract very few students. This is surprizing when taking into consideration that according to a survey conducted among teachers of Islamic RE in 2004, most of them expressed their interest for training that would qualify them as competent RE teachers. Due to lack of formal qualifications, teachers of Islam earned a minimum salary, which was a recognised problem both by the teachers and municipalities alike. (Sakaranaho \& Jamisto 2007.) The reasons for the above-mentioned low attendance might be various but one can mention at least three that have come up in discussions with the teachers.

In order to qualify as a teacher of religion in a Finnish comprehensive and upper-secondary school, a person needs, unlike in many other European countries, to have a Master's degree including a certain number of studies in the chosen school subject, coupled with pedagogic 
studies. In addition, one must have proficiency of Finnish language of the highest rank which is documented by taking Finnish matriculation exam or through a particular language test. Teachers of Islam, on the main, came from various countries, such as Somalia, Egypt, Morocco and so forth. Their level of education varies greatly; only very few of them have a university degree in Finland, while all of them have some training in their home country. However, even for a teacher who has received Master's degree in Finland, the language test can be a huge barrier. In this respect, the teacher requirements clearly reflect an understanding of a teacher who has gone through Finnish schools system and has next to perfect Finnish. In practice, this is the case for all of the Lutheran RE and for most of the Orthodox and Catholic RE teachers. The current system does not show much understanding for cultural and linguistic diversity.

In addition to lack of sufficient education and language skills, the third reason for teachers of Islamic RE for not attending teacher training in RE can be very practical; teaching Islamic RE is very demanding. Since there is only one or two hours of religious education per week, teachers of Islamic (and other minority) RE are compelled to circulate between numerous schools in order to fill in full-time schedules. In some cases, the same concerns also teachers of Lutheran RE but whereas they might have to commute between two or three schools at the most, teachers of Islam might have fifteen schools on their list. Consequently, they often have no school as a base and are not necessarily informed in time on changes in the school hours. (Sakaranaho 2006.)

In addition to the trying conditions concerning teaching in general, the classes that teachers of Islam face in their work are extremely heterogeneous. Muslim pupils, as Muslims in Finland in general, come from many different countries in North Africa, the Middle East, and Asia, or entered the country as refugees from Somalia, Kosova and Albania. Muslim pupils, therefore, represent different ethnicities and speak many different languages. Often the only language in common between teachers and their pupils is Finnish, which is also officially the main language used in class. In addition to ethnicity and language, pupils from different countries also vary due to their religious upbringing and the consequent amount of knowledge they might have about Islam. As one teacher said, a first-year pupil from Somalia might know much more about Islam than a fifth-year pupil from Kosovo. (Sakaranaho 2006.)

The heterogeneity of Muslim pupils notwithstanding, they often attend the same class of Islam. The reason for this arrangement is the lack of sufficient numbers of Muslim pupils on 
different year-levels. In order to have a full class, pupils from different year-levels are therefore collected together. Consequently, teachers have to align their teaching to address the needs of pupils with different levels of competence. When teaching pupils together from different grades, it is hard for a teacher to follow the Curriculum of Islam with detailed aims for each grade. This discrepancy between the principles of Islamic RE (curriculum) and the harsh reality of the classroom can be very trying for the teachers. What to some extent helps in teaching different grades of pupils are new text books recently made available by the National Board of Finland. (Salam - islamin polku 2013-2016.)

In addition to the above-mentioned and many other practical problems, teachers of Islam also face, in the aftermath of the recent Freedom of Religion Act (2003), a change in the law so that teachers of religion no longer need to be members of a registered religious community adhering to the religion they teach. According to this line of thought, training and qualification as a teacher guarantees a teacher's ability to teach fair and square also religious traditions other than one's own. The change in the law is of course congruent with the policy of separating religious education in schools from that of religious communities.

Consequently, the same teacher can teach different religions and secular Ethics provided that she or he has enough studies in the subject.

In recent years, more and more non-Muslim teachers have qualified as teachers of Islamic RE and due to their formal qualifications are stronger candidates for teaching positions of RE. With respect to teachers of RE, the current system favours native Finns who have gone through Finnish school system and are native Finnish (or Swedish) speakers. Some Muslim parents have expressed a concern for non-Muslim teachers not having enough knowledge and understanding of Islam but, for better or worse, they have no legal grounds for their demands. (Onniselkä 2011; see also Rissanen and Sai 2017, 8-9.) All in all, there is an interesting discrepancy in the current system where teachers of RE are not expected to be members of a religious community and hence can teach any religion but pupils attending their teaching are divided in accordance of their membership in a religious community.

\section{The Management of Muslim National Schools in Ireland}

As mentioned above, starting a Muslim primary school in Ireland went rather smoothly some three decades ago and today there are two Muslim national schools well-established in 
Dublin. In that sense, the "Catholic legacy" of ensuring religious communities the right to administer their own schools has worked well for Muslims in Ireland. However, religious ethos notwithstanding, schools should follow an overall curriculum designed for primary schools by Department of Education and Skills.

In practice schools are governed by a school board consisting of the patron, principal and parents, whereas the principal is in charge of the daily management of a school. However, a survey undertaken by the Irish Primary Principals Network (IPPN) showed that "many Principals have a challenging relationship with their Boards of Management" and that "most Boards do not understand where their role finishes and the Principal's role begins". (Cottrell 2008.) As shown in the Whole School Evaluation (WSE) conducted by the Department of Education and Skills (Whole School Evaluation 2013), similar problems have been noted in running both of the Muslim primary schools in Dublin.

The Whole School Evaluation Report in 2005 on the Clonskeagh Muslim National School positively assessed the in-school management of the school, the professionalism of the principal, teachers and school staff in their work and their commitment to the ongoing development of the school. With respect to pupils, the report was very positive about their engagement in the learning process and also noted that the school took well into consideration different cultural backgrounds of pupils, for instance, with the help of undertaking excellent cross-cultural projects in class. Finally, the evaluation report also noted that the school was doing a very good work regarding many areas of curriculum so that pupils were provided with a wide range of abilities. (Whole School Evaluation Report 2015, 10.) However, it reflected negatively on the fact that some parents opposed to teaching some aspects of music, history and physical education as contrary to their Islamic faith. In addition, there were Muslim parents who thought that a Muslim primary school should not have a non-Muslim as Principal. (Reilly 2009.)

In its report, the Department of Education recommended that a minority of parents should not have a decisive role in the governance of the Muslim national school. Instead, the Board should ascertain that, even though the school followed an Islamic ethos, the school curriculum entirely fulfilled the requirements of the national curriculum. The Department of Education did not see this as infringing on the parental right of choice regarding their children's education, granted by the Irish constitution. In its view, parents could always decide not to enroll their children in this particular school. (Whole School Evaluation Report 2005.) 
Whatever the case may be, changing school is easier said than done when taking into consideration that there are only two Muslim primary schools in Ireland and both of them are supported by the state and need to follow the overall primary school curriculum. In other words, parents in principle have a constitutional right to decide on their children's education in accordance with their faith but in practice their educational choices are limited by the state policies implemented top down. Moreover, this example illustrates how governments in practice make demands on the loyalty to national values of the state-supported schools irrespective of their religious ethos. In similar fashion to Finland, it also highlights the difficulties in coming to terms with religious diversity among Muslims (cf. Sai 2017).

\section{Concluding remarks}

This article took up two examples where a European state manages Islam in the field of education by means of incorporating Islamic education into the state-supported school system. In Finland, it is done as a part of religious education and in Ireland as a part of the denominational school system. Both of these states emphasize equality of all society members, irrespective of their religion, and in general show benevolence towards the religious diversity that these societies to an ever growing extent have been facing since the 1990s.

However, developing policies in relation to religious diversity is a very complicated issue and requires some sort of balancing act between requirements arising from age-old national traditions, on the one hand, and from the growing religious diversity, on the other. What the cases of Islamic education in Finland and Ireland readily illustrate, from the perspective of multilevel governance, is that there are clear discrepancies between the official rhetoric of equality and educational rights and that of education in practice. Both Finland and Ireland follow the model of extended privileges, whereby the establishment remains intact while some privileges are also granted to religious minorities. However, while this kind of top-down hierarchical way to govern Islamic education in Finland and Ireland might serve the national interests for uniformity and social cohesion, it is not truly sensitive to religious diversity, seeing Muslims as some sort of unitary whole rather than as a collection of people with a variety of views about Islam and life in general. In brief, one might describe this way to encounter religious diversity as a policy of "divide and rule". 


\section{References}

Alberts, Wanda. 2007. Integrative Religious Education in Europe. A Study-of-Religions Approach. Berlin: De Gruyter.

Bader, Veit. 2007. "The Governance of Islam in Europe: The Perils of Modelling." Journal of Ethnic and Migration Studies 33: 871-886.

Basic Education Act. 1998. (Amendments up to 1136/2010).

http://www.finlex.fi/fi/laki/kaannokset/1998/en19980628.pdf (accessed 18 November 2017).

Bråten, Oddrun M. H. 2013. Towards a Methodology for Comparative Studies in Religious Education. Münster: Waxmann.

Burchardt, Marian. 2017. "Diversity as neo-liberal governmentality: Towards a new sociological genealogy of religion”. Social Compass 64 (2), 180-193.

Constitution of Finland 731/1999 (2011). Unofficial translation. Ministry of Justice. http://www.finlex.fi/en/laki/kaannokset/1999/en19990731.pdf (accessed 18 November 2017).

Bunreacht na hÉireann / Constitution of Ireland (1937). Dublin: Government Publications, 2010.

Cottrell, San. 2008. "Challenge of School Management". International Confederation of Principals. IPPN: IPPN Publications. https://www.ippn.ie/index.php/advocacy/pressreleases/4936-1st-february-2008-sean-cottrell-direcor-ippn-addresses-800-principals (accessed 18 November 2017).

Cullen, Paul (2005), Classroom revolution: the changing ethnic mix in our schools. The Irish Times, April 12.

Fetzer, Joel S. \& Soper, J. Christopher. 2005. Muslims and the State in Britain, France, and Germany. Cambridge: Cambridge University Press.

Gauthier, François and Tuomas Martikainen. 2013.“'Introduction: Religion in market Economy". In Religion in the Neoliberal Age: Political Economy and Modes of Governance, edited by Tuomas Martikainen \& François Gauthier, 1-18. Ashgate: Farnham.

Himanen, T. 2012. Cultural Diversity, Social Cohesion, Religion: Core Values and Educational Policies in Four European Nations. Turku: University of Turku.

Hogan, Claire. 2011. "Accommodating Islam in the Denominational Irish Education System: Religious Freedom and Education in the Republic of Ireland," Muslim Minority Affairs, 31 (4), 554-573.

Holma, Markku. 2000. "Finland." In Religious education in Europe. A collection of basic information about RE in European countries, edited by Peter Schreiner, 37-41. Münster: ICCS / Comenius-Institute. 
Islamic Foundation of Ireland. Education. http://www.islaminireland.com/education/themuslim-national-school/ (accessed 17 November 2017).

Koenig, Matthias. 2007. "Europeanising the Governacen of Religious Diversity: An Institutional Account of Muslim Struggles for Public Recognition." Journal of Ethnic and Migration Studies 33 (6): 911-932.

Lukiolaki 455 / 2003: 9 §. http://www.finlex.fi/fi/laki/ajantasa/1998/19980629 (accessed 8 August 2014).

Laurence, Jonathan. 2012. The Emancipation of Europe's Muslims. The State's Role in Minority Integration. Princeton and Oxford: Princeton University Press.

Lukiolaki 455 / 2003: 9 §, http://www.finlex.fi/fi/laki/ajantasa/1998/19980629 (accessed 8 August 2014).

Martikainen, Tuomas. 2007. "The Governance of Islam in Finland," Temenos Nordic Journal of Comparative Religion 43: 243-266.

Martikainen, Tuomas. 2013. "Multilevel and Pluricentric Network Governance of Religion". In Religion in the Neoliberal Age: Political Economy and Modes of Governance, edited by Tuomas Martikainen \& François Gauthier, 129-142. Ashgate: Farnham.

Maussen, Marcel. 2007. The Governance of Islam in Western Europe, A State of the art report. IMISCOE Working Papers, No. 16. Amsterdam: IMER.

McGarry, Patsy. 2000. "Muslims wishing to practice should be facilitated." The Irish Times, 18 October.

Modood, Tariq, ed. 1997. Church, Staste and Religious Minorites. London: Policy Studies Institute.

Murray, John. 2008. "Is denominational education suitable for 21 st century Ireland?" The Irish Times, 7 April.

O'Loinsigh, Donal. 2001. "Intercultural Education and School Ethos." In Responding to Racism in Ieland, edited by Fintan Farrell and Philip Watt, 115-23. Dublin: Veritas.

Onniselkä, Suaad. 2011. "Islamin opetus kouluss.” In Mitä muslimit tarkoittavat? Keskustelua islamilaisista virtauksista Suomessa ja Euroopassa, edited by : Tuomas Martikainen and Tuula Sakaranaho, 122-138. Turku: Savukeidas.

Pauha, Teemu \& Martikainen, Tuomas. 2014."Finland", In Yearbook of Muslims in Europe, edited by Jørgen S. Nielsen, Samim Akgönül, Ahmet Alibašić \& Egdūnas Račius, 218-228. Leiden: Brill.

Perusopetuslaki 454 / 2003: 13 §. http://www.finlex.fi/fi/laki/alkup/2003/20030454 (last accessed 8 August 2014).

Reilly, Catherine. 2009. "Muslim school fight back - Principal claims criticism of teaching standards is 'politically motivated'". Metro Éireann, 22 October.

Rissanen, Inkeri. 2013. Negotiating Identity and Tradition in Single-faith Religious Education. Münster: Waxmann. 
Rissanen,Inkeri. 2006. "Teaching Islamic education in Finnish schools: A field of negotiations," Teaching and Teacher Education 28: 747.

The Rules for National Schools. 1965. Dublin: Government Publications.

Sai, Youcef.2017. "An exploration of ethos in Irish Muslim schools: ethnographic insights and perspectives of teachers and pupils." Journal of Beliefs and Values. Publishes online 28 February. DOI: 10.1080/13617672.2017.1290374 (accessed 18 November 2017).

Sakaranaho, Tuula. 2006. Religious freedom, Multiculturalism, Islam. Cross-reading Finland and Ireland. Leiden: Brill.

Sakaranaho, Tuula ja Eero Salmenkivi. 2009. "Tasavertaisen katsomusopetuksen haasteet:pienryhmäisten uskontojen ja elämänkatsomustiedon opetus Suomessa." Teologinen Aikakauskirja 114: 450-470.

Sakaranaho, Tuula. 2013. "Religious Education in Finland," Temenos, Nordic Journal of Comparative Religion 49 (2), 9-35.

Tuula Sakaranaho. 2015. "The Governance of Islam in the Republic of Ireland: Freedom of Religion and Islamic Education." In Muslims in Ireland: Past and Present, co-authored by Oliver Scharbrodt, Tuula Sakaranaho, Adil Hussain Khan, Vivian Ibrahim, and Yafa Shanneik, 136-189. Edinburgh: Edinburgh University Press.

Sakaranaho, Tuula. Forthcoming. "The Governance of Islamic Religious Education in Finland: Promoting 'General Islam' and the Unity of all Muslims," In Muslims at the Margins of Europe: Finland, Greece, Ireland and Portugal, edited by Tuomas Martikainen, José Mapril, and Adil Khan. Unpublished manuscript.

Sakaranaho, Tuula \& Annukka Jamisto, toim. 2007. Monikulttuurisuus ja uudistuva katsomusaineiden opetus [Multiculturalism and the renewal of religious education]. Helsingin yliopisto: Uskontotiede.

Salam - Islamin polku (2013-2016). www.edu.fi/salam (accessed 18 November 2017).

Scheinin, Martin. 2001. "Koulujen uskonnonopetus ihmisoikeuksien näkökulmasta" [Religious education in schools from a human right's perspective]. Teologinen Aikakauskirja / Teologisk Tiedskrift 6: 515-517.

Seine, Harri. 2000. Uskonnonopetus Suomen oppivelvollisuuskouluissa 1900-luvulla [Religious education in Finnish comprehensive schools in the $20^{\text {th }}$ century]. Annales Universitatis Turkuensis. Turku: Turun yliopisto.

Seppo, Juha. 2003. Uskonnonvpaaus 200-luuvn Suomessa [Freedom of religion in the 21st century Finland]. Helsinki: Edita.

Ubani, M. (2013). Threats and solutions. Religion and multiculturalism in educational policy. Intercultural education, 24(3), 195-210.

Uskonnonvapauslaki 2003/ 453 [Freedom of Religion Act]. http://www.finlex.fi/fi/laki/ajantasa/2003/20030453 (accessed 18 November 2017). 
Whyte, J.H. 198. Church \& State in Ireland 1923-1979. Dublin: Gill and Macmillan Press.

Whole School Evaluation Report. 2005. The Muslim NS, Roll number 19949B. Dublin: Department of Education and Science.

Whole School Evaluation. 2009. Dublin: INTO education committee. 